\title{
Finnish Archaeologists' Contacts with the Baltic Countries during the Second World War
}

\author{
Timo Salminen \\ Department of Philosophy, History, Culture \\ and Art Studies (Archaeology), \\ University of Helsinki \\ P. O. Box 59 (Unioninkatu 38 F), \\ Helsinki Fl-00014, Finland \\ E-mail: timo.salminen@pp3.inet.fi
}

\begin{abstract}
Finnish archaeologists, especially Aarne Michaël Tallgren, had established contacts with their colleagues in the Baltic countries before the Second World War. In the summer of 1939, the world situation became a dominant theme in letters between archaeologists. The outbreak of war in Europe and the military base negotiations in Moscow evoked increasing concern. After the Soviet attack on Finland, only a few Finnish and Baltic archaeologists stayed in contact, but communications revived quickly after the Finnish-Soviet peace treaty of 1940. Estonian archaeologist Harri Moora saw the trials of war as a punishment for forgetting all spiritual values in previous years. The Soviet occupation of the Baltic countries in 1940 broke all contacts for longer than a year. After Germany had occupied the Baltic countries in 1941 and was allied with Finland in war against the Soviet Union, connections could be resumed to some extent. Tallgren, together with the Swedish State Antiquarian Sigurd Curman, now started planning the evacuation of children from Estonia to Sweden. In 1942, scholarly discussion returned to the correspondence, although only on a practical level, but already in early 1943 all correspondence became impossible. At the same time, Finnish archaeologists were in contact with Baltic refugees, especially Francis Balodis from Latvia. There were also Scandinavian and British archaeologists with whom Finnish researchers exchanged information about colleagues in the Baltic countries. The communications mainly focused on three things: getting and spreading information regarding the current situation, offering both practical help and psychological support to colleagues in the Baltic countries, and attempting to re-establish the exchange of ideas within the scholarly community.
\end{abstract}


Keywords: archaeologists and society, Baltic Sea region, history of archaeology, scholarly networks, Second World War

\section{Historical background and research problems}

Estonia, in particular, was one of the most important contact areas for Finnish archaeologists between the World Wars. Johan Reinhold Aspelin (1842-1915) had already helped Estonian archaeology enthusiasts in their work in the 1880s. Aarne Michaël Tallgren (1885-1945) worked as the first ordinary professor of archaeology at the University of Tartu in 1920-1923. He schooled the first generation of Estonian archaeologists and started the archaeological research of the country. Tallgren's pupils adopted the Scandinavian conception of archaeology following the so-called culture-historical type of research based on a comparative typological approach. Museum institutions were also built according to Finnish and Scandinavian models. Tallgren and his Estonian pupils were also active in the archaeological research of Latvia in the 1920s. (Lang, 2006, pp. 19-23; Salminen, 2014, pp. 21-22, 69-70, 81) This shows that Tallgren had lively contacts especially with Estonia, but to some extent also with Latvia. Through Tallgren, Aarne Äyräpää (1887-1971) established a network of contacts among his Estonian colleagues. The liveliest period of Finnish archaeological contacts with the Baltic countries was in the 1920s, but especially Tallgren actively corresponded with his former pupils until the outbreak of the war. Harri Moora (1900-1968), Eerik Laid (1904-1961), and Marta Schmiedehelm (1896-1981) were his most important contact persons in Estonia. In Latvia, Tallgren stayed in contact with Professor Francis Balodis (1882-1947) and some younger researchers such as Eduards Šturms (1895-1959). There were no significant contacts between Finnish and Lithuanian archaeologists after Tallgren left Tartu in 1923 (Salminen, 2014, pp. 71, 88, 177, 378).

What did the Finnish archaeologists know about the situation in Estonia and Latvia and their colleagues there during the war? What were the main channels for acquiring information? What kind of grass-roots image did Estonian and Latvian archaeologists give of the situation in their home countries? Was there any scholarly discussion between Finnish archaeologists and their colleagues in the Baltic countries during the war? How were archaeologists from other countries involved in the discussion? Did the contacts have any significance for research and science? How did archaeologists and their close colleagues from 
other disciplines experience the situation on a personal level? The main goal of this paper is to investigate the scholarly community from a micro-historical point of view and thus provide a look on how it functioned in exceptional circumstances. Its focus is not only on research itself but also on researchers' role in society in general (see also Salminen, 2014, pp. 258-293; 2015, pp. 187-198).

\section{Outbreak of war}

The outbreak of the world war in Europe severed a large part of international scholarly cooperation. In the Baltic Sea region, the change was especially big in Estonia, Latvia, and Lithuania. In the non-aggression pact of August 1939, Germany and the Soviet Union divided Eastern Europe into two spheres of interest. This enabled the German invasion of Poland and outbreak of the war. Germany also invited the Baltic Germans "home to the Reich", that is, emptied the Baltic countries of their German population before the coming Soviet invasion. The medievalist Paul Johansen (1901-1965) complained to the Finnish archaeologist and art historian Carl Axel Nordman (1892-1972) how difficult it was for him to leave his home in Tallinn ${ }^{1}$ (Salminen, 2015, p. 14). In the second half of September, the Soviet Union required the establishment of military bases in Finland, Estonia, Latvia, and Lithuania. The Baltic countries agreed, and in October, Soviet troops were transported to the bases (Zetterberg, 2007, pp. 609-616).

The change in the position of the Baltic countries was immediately reflected in the correspondence between Tallgren and his Estonian colleagues. A very intensive period of writing began. After the German invasion of Poland, the linguist Ants Oras (1900-1982) wrote to Tallgren about the mood in Estonia: ${ }^{2}$

The shock is profound everywhere. War is a terrible phenomenon, but if it helps to make the world more humane again, it may be inevitable. Anyway, it is depressing to see how the criminality or insanity of the person mentioned in your letter has ruined all attempts at a solution. And mainly only those people suffer who are least involved with political developments. Perhaps the wounds of this war will be incurable, at least for several generations to come. Of the previous war, Communist, Fascist, and National Socialist psychoses were born-what kind of psychoses will follow this one? And how much

Paul Johansen's letter to C. A. Nordman, 24 Oct 1939 (SLSA, 1913-1972).

Hereinafter, all translations of the correspondence in Estonian by the author. 
will it destroy direct cultural values? How many talents? Will the war not be followed by a shortage of creative forces that will cause the world to suffer for decades? The Thirty Years' War was followed by an even longer period of suffering in Germany. [...]

I cannot find balance. I'm afraid that also this time, this thing will last a very long time. And we cannot help it in the slightest.

The Poles are getting too bitterly punished for their behaviour against the Czechs. The world was really blind last year. ${ }^{3}$

In his next letter, Oras continued:

Yes, we don't know what will happen in the near future. I cannot work properly either. Anything I could do seems too little and too insignificant, at least now. Of course, I must carry out my everyday work, but it is not possible to focus more deeply on anything.

I don't believe that the warmonger and initiator in Germany will become the ruler of the world. I believe in the Allies, and I also believe that America will later take part-even if the Congress session tomorrow ends in failure. But it seems almost inevitable, however, that the world will emerge from the struggle in different shape, that not very much creative work will be done for decades, that coarseness and lack of principles will flourish everywhereunless there is a big internal turn, which could also be imagined. [...]

If there have ever been preconditions for a destruction of European culture, they exist now. [...]

Maybe America will have quite a big role to play in our intellectual regeneration.

All this is, of course, connected with the expectation that the democracies will win. I suppose they will, and they will do it as democracies. But what

3 Ants Oras' letter to A. M. Tallgren [hereafter abbreviated AMT], 11 Sep 1939 (KK, 1838-1956): “Vapustus on igal pool póhjalik. Söda on kohutav nähtus, aga kui see aitaks maailma jälle humaansemalt korraldada, siis see vöib-olla on paratamatus. Ometigi on masendav näha, kuidas sinu kirjas mainit isiku kuritegelikkuse vôi hullumeelsuse tôttu köik rahulikud lahenduskatsed on purunend. Ning kannatavad päämiselt need, kellel poliitilise arenguga on olnud köige vähem tegemist. Vöib-olla osutuvad selle sója haavad parandamatuks, vähemalt mitme pölve jooksul. Eelmisest sōjast sündisid kommunistlik, fašistlik, rahvussotsialistlik psühhoos millised psühhoosid järgnevad käesolevale? Ja kui palju hävitatakse otseseid kultuurilisi väärtusi? Kui palju andeid? Kas sōjast ei teki loovate võimete pöud, nii et maailm peab kiratsema aastakümneid? 30-aastasele söjale järgnes veel hoopis pikem kiratsemine Saksas. [...] Ei suuda leida tasakaalu. Kardan, et seegi kord asi kestab väga kaua. Ja meie ei saa sinna vähimalgi määral parata. Poolakad saavad liiga kibedasti karistada oma käitumise eest tšehhide vastu. Aasta eest maailm oli tóesti pime." 
will prophesying help? We shall do what we can as long as it is possible for us. ${ }^{4}$

Tallgren's pupil Harri Moora (1900-1968), by then professor of archaeology at the University of Tartu, wrote his teacher on the same day as the Estonian representatives signed the treaty regarding military bases in Moscow with the Soviet Union:

But the recent days have put us in a situation that really worries all of us. We do not yet know what is planned for Estonia in Moscow at the moment, but it is everything but good. Russian planes fly demonstratively not only over the border but also over the major cities in recent days and Russian newspapers are full of invented stories - this predicts rather bad things. I am especially saddened by my powerlessness to do anything to amend or save the situation. And, as mentioned, only work, which I grasp at almost convulsively, takes these thoughts away. ${ }^{5}$

According to Moora, life was externally unchanged, but the people had become serious. Work at the excavations and with the finds had helped him. Moora hoped that the Estonians' opportunities in life and work would not be stifled forever as "violence and untruth can hardly triumph in the end". ${ }^{6}$

At the beginning of October, the Finnish museum people sent, via Harri Moora, their Estonian colleagues a letter to express their sympathy. When Moora thanked the Finns for the letter, he said that the knowledge that the Estonians had not been forgotten gave them strength in hard times, when they could not actually

4 Ants Oras' letter to AMT, 20 September 1939 (KK, 1838-1956): "Jah, ega tea, mis lähemad ajad toovad. Ise ma samuti ei saa korralikult töötada, Köik, mida ise saab teha, tundub väikesena ja vähemalt praegusel ajal vähetähtsana. Muidugi tuleb teha oma igapäevast tööd, kuid millessegi tôsisemalt süveneda ei saa.

Ma ei usu, et too sójaóhutaja ja -algataja Saksas saab maailma valitsejaks. Mul on usku liitlastesse ja samuti sellesse, et Ameerika pikapääle vótab asjast osa - isegi kui homme kongressi istung peaks löppema ebaönnestumisega. Kuid et maailm ka vaikselt tuleb vöitlusest välja teissugusena, et aastakümnete jooksul enam ei tehta kuigi palju loovat tööd, et toorus ja printsiibitus kasvavad igal pool, see näib küll peagu paratamatuna - kui hädade tôttu ei tule mingit suurt sisemist pööret, mis on ju ka móeldav. [...]

Kui on kunagi olnud eeldusi Euroopa kultuuri hävimiseks, siis on need praegu olemas. [...]

Vöib olla, et Ameerikal meie pälastiks vaimses regenereerimises on veel üsna suur osa etendada.

See köik on muidugi seotud ootusega, et demokraatiad vöidavad. Arvan, et nad seda teevad ja et nad seda teevad veel demokraatiatena. Kuid mis ennustamine aitab? Teeme, mis me saame, nii kaua kui meil on selleks vóimalust."

$5 \quad$ Harri Moora’s letter to AMT, 28 September 1939 (KK, 1838-1956): "Viimased päevad on aga meid endid asetanud seisukorda, mis teeb köigile suurt muret. Mis praegu Eesti kohta Moskvas kavatsetakse, pole meile veel teada, aga köike mund kui hää see on. Kui Vene lennukid viimastel päevadel käivad meeleavalduslikult mitte ainult üle piiri vaid ka suuremate linnade kohal ja kui Vene lehed on täis väljamöeldusi - siis ennustab see kogemuste järgi üsna halba. Kurvaks teeb eriti jöuetus midagi asja parandamiseks või päästmiseks ette vôtta. Ja nagu öeldud, ainult töö millest praegu peaaegu kramplikult kinni hoiad, viib mötted eemale.”

$6 \quad$ Harri Moora’s letter to AMT, 28 September 1939 (KK, 1838-1956): "ega vägivald ja vale lóplikult siiski vöi jä̈̈da triumfeerima." 
see forward but acted only instinctively. The Moscow pact had brought relief that the worst did not follow, but the mood was low again, because the country was practically occupied, and nobody knew what would further be lost. Moora also hoped that Finland would deal with its situation with more dignity than Estonia. $^{7}$

\section{A weak thread of contact in 1939-1940}

Also Finland had to send its representatives to Moscow to negotiate over the bases. Since the Soviet Union did not get what it wished, it declared war on Finland on November 30, 1939.

From that point on until the middle of March 1940, Finland was at war. International connections were disturbed, but not completely severed. In the correspondence, the Finnish-Soviet war was often seen as a battle between civilisation and barbarism or West and East. It thus continued a long tradition of interpreting the Finnish-Russian relationship. (Salminen, 2014, pp. 261-267)

Finns could, in principle, keep in contact with the Baltic countries, but there was no correspondence within the archaeological community, because people with interest in keeping in touch did not have practical possibilities to write. Tallgren got one letter from Estonia during the winter of 1939-1940, from Aliise and Harri Moora. They wished God's protection on Finland and asked to stay friends with their Finnish colleagues ${ }^{8}$ (on the Estonians' attitudes to Finland see Rui, 2006, p. 307).

Since the war had caused a problematic situation between Finland and Germany, the Ministry of Education appointed a committee to plan Finnish cultural propaganda in different countries. The committee drew up a list of Finnish scholars whose international contacts were deemed useful in the prevailing situation. The committee hoped that Tallgren would transmit the Finnish message to the Baltic countries. (KA, 1940) The Finnish-Soviet peace treaty was signed before Tallgren had an opportunity to do anything.

The Finnish Ministry of Foreign Affairs sent Professor Lauri Kettunen (18851963) to Tallinn and Tartu in January 1940 to study, among other things, the

\footnotetext{
Harri Moora's letter to AMT, 12 October 1939 (KK, 1838-1956).

8 Aliise and Harri Moora's letter to AMT, s. d. December 1939 (KK, 1838-1956).
} 
attitudes among Estonian scholarly circles towards Finland and its war. FinnishEstonian relations were poor, because Estonia had a contractual relationship with the Soviet Union, which was at war with Finland. The Estonian private sympathies were, however, on the Finnish side. (Rui, 2006, pp. 299-300, 306-308)

\section{A short period of peace in Finland in 1940-1941 and the occupation of the Baltic countries}

Finland and the Soviet Union signed a peace treaty in Moscow on March 13, 1940. Finland had to cede a whole province to the Soviet Union and lease a military base to it on the southern coast of the country. The Soviet Union also continued to express political pressure towards the government of Finland.

Soon after the peace treaty, Tallgren wrote to two of his most important British colleagues, Ellis Hovell Minns (1874-1953) and Vere Gordon Childe (18921957). Referring to Tallgren's letter, Childe stated in his reply: "As you say, if the Allies are defeated, Europe at least is indeed doomed to a Dark Age. Perhaps you in the Baltic States will still be able to keep alive the standard of free scientific research". Here, by the ${ }^{9}$ Baltic States he meant the Baltic Sea region from Lithuania via Sweden to Finland. ${ }^{10}$ Minns did not comment on the situation until some months later.

Harri Moora wrote to Tallgren in an extremely pessimistic tone on June 11, 1940:

It seems that our generation will get the punishment you once feared. I am more and more convinced that this is because all the values we had, freedom, honesty, faith, were taken in a relative sense, in real life they had significance only as words. This half-heartedness or dislike brought about an opposition that did not and does not want to deal with words, and instead wanted and

$9 \quad$ Vere Gordon Childe's letter to AMT, 5 June 1940 (KK, 1838-1956).

10 Harri Moora’s letter to AMT, 11 June 1940 (KK, 1838-1956): "Meie pólv saab nüüd nähtavasti kätte selle karistuse, mida mónikord kartsid. Minus on kasvanud veendumus, et see on selle eest, et köiki väärtusi, mis meil on, vabadust, ausust, usku võeti relatiivselt, need maksid tegelikus elus ainult sõnades. See poolikus või vastuoksus tekitas opositsiooni, kes sõnu ei tahtnud teha ja kes tahtis ja tahab ehitada ainult "realiteedile", vöimule ja kes midagi körget ei usu ja see vool sö̈b nü̈̈d inimkonna ja kultuuri ära. Nähtavasti peab maailm purunema, et siis jälle tuhast tôusta paremana ja ausamana. Aga seda meie küll enam ei näe. Meie ja meie lapsed on vist määratud selleks pölveks, kes peab nägema ja läbi elama seda, kuidas inimesed ilma körgemate vaimsete väärtusteta endid hävitavad. See on hirmus perspektiiv, aga me peame olema seda ära teeninud, ega muidu niisugust karistust meile ei saadetaks." 
wants only to build on "reality", power, and that does not believe in any higher values. This kind of current is now destroying mankind and culture. It seems that the world must be destroyed to rise from the ashes better and more honest. But we will not be there to see it. We and our children are probably predestined to be the generation that must see and experience how people without higher intellectual values destroy each other. It is a terrible perspective, but we must have deserved it, because otherwise that kind of punishment would not be sent to us. ${ }^{11}$

The Soviet Union occupied all three countries in June, changed their governments, and staged elections, in which only Communist candidates were allowed to take part. The elected parliaments formally applied for inclusion of their countries into the Soviet Union in July. Because of the war, the incorporation, in practice, meant only continuing the military occupation. It was Germany's advance in the west that had made the Soviet Union act. (Zetterberg, 2007, pp. 620-635)

Immediately after the incorporation of the Baltic countries into the Soviet Union, Tallgren wrote a letter to Moora in mixed Finnish and Estonian:

Dear brother,

- So. It has happened then. No balance can be found. Nothing can be done. I love Estonia more than my own country. I bow my head before you and others. With respect. Sorrow and yet more respect. Your country will survive: the intelligentsia and free peasants still live. You have the skills, wisdom, goodness, and experience of centuries in your blood. Viva Estonia. Fate, God, protect its people-it does not hate, give it a happy future.

We are all off the rails, nervous. And even then: a greatness of spirit and organisational skills are your weapons. That people will not perish. It will live. ${ }^{12}$ (Moora's family collection, 1927-1968)

\footnotetext{
11 "Armas vend,

— Nii. See on siis sündinud. Ei suuda leida tasakaalu. Ei saa sinna vähimalgi määral parata. Ma armastan Eestit enam kui oma maat [sic]. Painutan oma pää Sinu ja teiste ees. Austusega. Kurbtusega ja veel kord austusega. Su maa jääb seisma: intelligents ja vabad talupojad elavad. Teil on oskust, tarkust, tublidust ja vuosisatain kokemus veressä. Elagu Eesti. Kaitselmus, Jumala, suojaa sen kansaa - se ei vihaa, anna sille onnellinen tulevaisuus.

Oleme köik roopast löödud, närvilised. Ja sittenkin: hengen suuruus ja organisaatiokyky ovat teidän aseenne. Se kansa ei tuhoudu. Ta elab."

12 Sigurd Curman's letter to Carl Axel Nordman, 21 June 1940; 3 August 1940 (SLSA, 1913-1972).
} 
In August 1940, the State Antiquarian of Sweden, Sigurd Curman (1879-1966), referred to the Baltics and expressed once more his serious concern over what would happen with Finland. ${ }^{13}$

In July 1940, Ellis Minns asked Tallgren for news from Latvia, especially concerning Francis Balodis, Valdemārs Ģinters (1899-1979), and Elvīra (19051996) and Rauls Šnore (1901-1962). This shows that he had at least been informed about relatively many Latvian archaeologists' work before the war, obviously because of his acquaintance with Balodis. ${ }^{14}$ Tallgren replied among other things:

The times have been severe. So far all your acquaintances live, archaeologists, all at the museum, my own. Also the archaeologists in Estonia and Riga. The destruction of the Estonian Republic has taken me hard. It is a worthy and human people with self-discipline and goodness of will. It stood in the way of nobody and I admire its educated youth. The Estonians were never extreme. May this dreadful war soon be finished. ${ }^{15}$

In late 1940, Tallgren tried to connect with his colleagues in occupied Estonia. The Swedish archaeologist Holger Arbman (1904-1968) promised to help him, although he admitted that the task was difficult. He had not heard anything from Estonia for a long time, either, and "everything is upside down in these evil times". The contact attempts had no success at that time. ${ }^{16}$

It was already April 1941 when Tallgren received some information on the circumstances in Estonia, although not from people within the country. The first to write was the brewer and active amateur archaeologist Eduard Gustav Bliebernicht (1902-1943), who had moved from Pärnu to Germany and informed Tallgren of the situation of his pupils in Estonia. According to Bliebernicht, ethnographer Ferdinand Linnus (1895-1942) had worked as director of the Estonian National Museum and archaeologist-ethnographer Eerik Laid as his assistant. Pärnu Museum had been nationalised. This was all he knew. ${ }^{17}$

13 E. H. Minns' letter to AMT, 11 July 1940 (KK, 1838-1956).

14 AMT's letter to Minns, sketch s. d. 1940 (KK, 1838-1956). Tallgren's archive contains both a Swedish original text of the letter and an English translation. It was typical of Tallgren in his later years that he often wrote his letters in Finnish or Swedish and had them translated.

15 Holger Arbman's letter to AMT, 15 December 1940 (KK, 1838-1956).

16 E. G. Bliebernicht's letter to AMT, 14 April 1941 (KK, 1838-1956).

17 Sten Karling's letter to AMT, 22 April 1941 (KK, 1838-1956). Sten Karling described the situation in Estonia in several letters to Sigurd Curman (Karling's letters to Curman dated to 8 December 1939, 17 April 1940, 1 May 1940, 18 June 1940, 28 October 1940, 26 December 1940, 13 January 1941; ATA, 1881-1966). 
A week after Bliebernicht, Sten Karling (1906-1987) wrote from Sweden. He had worked as professor of art history at the University of Tartu until the winter of 1941. The Soviet government had dismissed him then, but because of difficult ice conditions in the Baltic Sea, he had had to wait until he could return home. Hewrote that he had witnessed both intellectual and material terror by the Soviet occupiers, and he had also seen how the Soviet system was brought into a country with a higher standard of living than the Soviet Union. Circumstances had deteriorated rapidly, but academic circles had suffered relatively little so far. All archaeologists were alive and had been able to keep their offices. Professor of history Hans Kruus (1891-1976), who had been appointed rector of the university, had tried to save what could be saved, but Karling did not believe Kruus could do much against the Communist Party, of which he was a member. Karling supposed that Kruus would probably tragically sacrifice himself. ${ }^{18}$ (Wieselgren, 1942, pp. 72-237)

Tallgren asked for more information. Karling further told him that Tallgren's former patron, attorney, Consul Oskar Rütli (1871-1949) from Tartu, had suffered great economic losses, but lived in Otepää in south-eastern Estonia. His house had been changed into a military hospital. It was prohibited to print books in foreign languages, which had profoundly disturbed the activities of the Learned Estonian Society (Est. Opetatud Eesti Selts). According to Karling, the standard of living of those with small incomes had deteriorated steeply. The theological faculty of the University of Tartu had been closed and the church was in difficulties, but churches were full of people. Of Tallgren's humanist acquaintances, the director of the Estonian Folklore Archives Oskar Loorits (1900-1961) still held his office. The Estonian National Museum was undamaged; Linnus was its director and Laid his assistant. There had been more reorganising in the museums of Tallinn. Archaeologists attempted to establish professional contacts with Russia, and the museum people had visited there in the winter. Plenty of Russian literature was coming, but nothing from elsewhere. ${ }^{19}$ (Kirm, 2011)

Another Swedish professor, Per Wieselgren (1900-1989), stayed in Tartu through the whole "red" or first Soviet year and published a book about his experiences in 1942. Sigurd Curman wrote to Tallgren in December 1941 about what he had heard from Wieselgren: the director of the Estonian National Archives, Otto Liiv (1905-1942), was in Tartu, but Ferdinand Linnus and art historian Villem Raam (1910-1996) had been taken to Russia. In July 1942, Curman knew that Moora, Laid, and classical scholar Pärtel Haliste (1890-1944) were

18 Karling's letter to AMT, 11 May 1941 (KK, 1838-1956).

19 Curman's letters to AMT, 24 November 1941, 18 December 1941, 31 July 1942 (KK, 1838-1956). 
well in Tartu, but Linnus and art historian Armin Tuulse (1907-1977) had gone away. ${ }^{20}$ (Wieselgren, 1942)

The occupation brought about the first wave of refugees from the Baltic countries. Among others, Professor Francis Balodis escaped from Riga to Stockholm, where he had had lively contacts already for ten years. Antiquarian Bengt Thordeman (1893-1990) wrote to C. A. Nordman about the shocking things that Balodis and others had told him, and hoped that the Soviet-German pact would not apply to Finland ${ }^{21}$ (see also Kumer-Haukanōmm, 2006, pp. 14-15).

Tallgren wrote to Balodis in the middle of October 1941. In his reply, Balodis told about the reorganisation of the Latvian University. Eduards Šturms had been appointed to Balodis' former chair. Balodis characterised Šturms as the only Latvian archaeologist who had taken up contacts with Communists. ${ }^{22}$ Here we must take into account, however, that the personal relations between Balodis and Šturms had been strained already in the 1930s. So Balodis probably fostered a negative image of Šturms based on their earlier relationship, without actual knowledge of Šturms' attitudes and actions. ${ }^{23}$ (Salminen, 2014, p. 180; see also Rui, 2006, pp. 314-320) The image was gloomy, but, in the light of later research, realistic (Zetterberg, 2007, pp. 620-640).

Most researchers survived the red year, mostly because the Soviet government did not have time for thorough purges. However, they had to adapt their teaching to the new rules and report their international contacts, visits, and meetings to the occupying powers. Foreign literature was not purchased. These were the first steps in isolating the scholarly community of the Baltic countries from the west. (Rui, 2006, pp. 310-313; see also Wieselgren, 1942, pp. 164, 198)

Harri Moora acted for two months as Deputy Minister of Education in the Soviet government of Estonia in the summer of 1940. For that, he lost his professorship in Tartu in 1942 and had to move to Tallinn to work as museum director there ${ }^{24}$ ('Harri Moora...', 1970, p. 19; Marksoo, 1999, pp. 125-126).

Journalist Paul Olberg (1878-1960) published a book called Tragedin Balticum ('The Baltic tragedy'), which Tallgren commented to him. Tallgren stated that the

$20 \quad$ Bengt Thordeman's letter to Nordman, 2 August 1940 (SLSA, 1913-1972); Francis Balodis' letter to Nils Åberg, 30 December 1941 (ATA, 1890-1992).

21 Balodis' letter to AMT, 19 October 1940 (KK, 1838-1956).

22 Eduards Šturms' letter to AMT, 12 June 1935 (KK, 1838-1956).

23 Moora's letter to AMT, 19 March 1942 (KK, 1838-1956).

24 AMT's letter to Paul Olberg, [a sketch] 19 April 1941, Olberg's letter to Silvia [Sylvi-Kyllikki] Kilpi, 14 April 1941 (KK, 1838-1956). 
sovereignty of peoples had had to step aside before international illegality, but he predicted that the spirit would be stronger than power and violence. According to Tallgren, the only solid basis for world order was built on constitutional states with social justice and solidarity between citizens. Olberg was a former Menshevik politician and writer, who came from Riga, had escaped to Germany after the Russian Bolshevik revolution of 1917, and had further escaped to Sweden after Hitler's rise to power. ${ }^{25}$

If we look at the discussion between Finnish and Estonian archaeologists before the summer of 1941, it typically concentrated on the general circumstances in Estonia. Scholarly and work-related questions had to give way; only Harri Moora mentioned them briefly in summer 1940. Nevertheless, archaeological fieldwork was carried out in Estonia in the areas that were given to the Red Army, but the Finns and Estonians could not freely exchange information about these excavations. In Finland and Latvia, archaeological work was more or less at a standstill. (NMF diary, 1941-1944 in MVA, 1828-2015; Laul, 2011, pp. 228-229; Lang, 2006, p. 28; Šnore, 1974, p. 12)

Since Swedes were also actively seeking contact with the Baltic countries, a multilateral network of researchers was formed with the aim of getting information from Estonia as reliably as possible.

\section{Finland by Germany's side}

Finland's situation changed rapidly in 1941. Germany was given permission to transport its troops via Finland to northern Norway, and in May-June 1941, Finland and Germany agreed on cooperation against the Soviet Union. Germany invaded the Soviet Union on 22 June, partly from Finland's territory, and the Soviet Union attacked Finland three days later with no declaration of war. Finland sought for the restoration of the borders of 1939, but also shared Germany's goal of destroying the Soviet Union. By the autumn of 1941, the Finnish army advanced at first to the old border and then crossed it to Russian Karelia. Thereafter the situation stagnated until the summer of 1944. Researchers were tasked with finding scientific grounds for annexing Eastern Karelia to Finland.

25 AMT's letter to Curman, 26 July 1942 (ATA 1881-1966). At about the same time, Curman got a letter from Harri Moora in Estonia, in which Moora described the situation both in Estonia and Latvia. The letter is preserved among Adolf Schück's Baltic material. (Handlingar ang. samarbete med Baltikum, Moora's letter to Curman, 7 July 1942, ATA 1925-1959) 
(On researchers in Eastern Karelia during the war see Pimiä, 2009, pp. 30-43; Hietala, 2006, pp. 98-128; Nordqvist \& Seitsonen, 2008, pp. 40-45; Salminen, 2008, pp. 148-151.)

Postal connections from Finland remained mainly to Sweden and Germany and some German-occupied countries. While Finns had been unanimous in 19391940, the new situation was more problematic. Also archaeologists were divided. Especially for English-minded persons like Tallgren, adapting to the situation was difficult. Tallgren was frustrated also because, officially, Finland did so little for Estonia and Estonians. ${ }^{26}$

Little archaeological fieldwork was carried out during the war. There were some exceptions, though, such as the Finnish excavations in the occupied Eastern Karelia in 1943 (NMF diary, 1828-1915; Nordqvist \& Seitsonen, 2008, pp. 40-45). It is not known what kind of information Tallgren or other Finns were able to send to their colleagues in Estonia. The Finns' immediate contacts with Latvia were completely broken.

\section{The Baltic countries from one occupation to another}

Germany withdrew the Red Army from the Baltic countries in late summer 1941. The new period of German occupation meant a change, but conditions were not always better for scholars compared with the Soviet year. Mostly, only research that served military goals could continue. Scholars were still imprisoned. (For an eyewitness description of the decisive battles in Tartu see Wieselgren, 1942, pp. 204-237; on German occupation and Estonian science see Rui, 2006, pp. 322-323.)

Already in July 1941, Tallgren wrote to Sigurd Curman in Stockholm about the difficult situation in Estonia and suggested that children should be evacuated from Estonia to Sweden. There were already Finnish children in Sweden. One group could consist of Estonian-Swedish children, but also others could be transported. Curman supported the idea, and Tallgren was ready to go to Estonia to get information about the situation as soon as the country was free of Russians $^{27}$ (also, Åman, 2008, pp. 190-192).

26 Curman's letter to AMT, 11 July 1941 (KK, 1838-1956); AMT's letter to Curman, 5 July 1941 (ATA, 1881-1966).

27 AMT's letter to Curman, 17 July 1941 (ATA, 1881-1966); cf. AMT's letter to Curman [a sketch], 17 July 1941 (KK, 1838-1956). 
Tallgren contacted Finnish authorities and child welfare organisations, but also the former Estonian ambassador in Helsinki, Aleksander Varma (1890-1970), who had promised to send a message to the Estonian Red Cross. ${ }^{28}$ According to Curman, the Swedish Red Cross was ready to act in all Baltic countries as soon as the battles subsided. In November, he wrote that legates of the Swedish government were expecting permission from the German authorities to enter Estonia, but they could not actually get into the country until the spring of 1942..$^{29}$ The plan could not be realised.

Francis Balodis wrote to Tallgren in August with news from Latvia. He wanted to go home, but because the news was not pleasing, he still had to stay in Sweden. ${ }^{30}$ Also, Ture Johnsson Arne (1879-1962) related to Tallgren what he had heard from Balodis: according to him, museums in Tartu and Riga were undamaged, but archives had suffered extensively. ${ }^{31}$ In late 1941, it was Balodis' turn to ask Tallgren for news. He also wrote that he had not received permission to return home. In January 1942, he complained of being homesick again and stated that Tallgren's pessimism made him sad. ${ }^{32}$

In March 1942, Balodis knew that all Latvian archaeologists were alive and working. He had heard Ģinters on radio and read about Rauls Šnore, Adolfs Karnups (1904-1973), and Eduards Šturms in newspapers. His homesickness was still worse. "Doch das Schicksal verlangt ja Geduld". ${ }^{33}$ He could not understand at all that the Germans had appointed Carl Engel (1895-1947) professor in Riga in his former chair in $1942 .{ }^{34}$

Balodis' humour was not improved by an article by the young German historian Wilhelm Koppe (1908-1986) in the journal Jomsburg. Koppe described Balodis as a historian and politician and considered his Latvian prehistory (published in Latvian in 1938, and in Swedish in 1941) mainly a political work. Latvian and German nationalist views of prehistory collided in this controversy. Also Tallgren and Curman discussed the event. ${ }^{35}$ (Balodis $\&$ Tentelis, 1938; Balodis 1941)

\footnotetext{
28 Curman's letters to AMT, 10 August 1941, 24 November 1941, 18 December 1941, 31 July 1942 (KK, 1838-1956).

29 Balodis' letter to AMT, 10 August 1941 (KK, 1838-1956).

30 T. J. Arne's letter to AMT, 30 August 1941 (KK, 1838-1956).

31 Balodis' letter to AMT, 14 December 1941, 23 January 1942 (KK, 1838-1956).

32 Balodis' letter to AMT, 7 March 1942 (KK, 1838-1956).

33 Balodis's letter to AMT, 10 July 1942 (KK, 1838-1956).

34 Balodis' reply to Koppe's article, Curman's letter to AMT, 31 July 1942 (KK, 1838-1956); AMT's letter to Curman, 26 July 1942 (ATA, 1881-1996).

35 Laid's letter to AMT, 23 October 1941 (KK, 1838-1956).
} 
After the beginning of the German occupation, Tallgren finally received firsthand information from Estonia when Eerik Laid wrote in October 1941. According to Laid, all scientific and social institutions were undamaged in Tartu. Soviet authorities had arrested the director of the Estonian National Museum, Ferdinand Linnus, on 28 June and transported him near Vyatka, but all Tallgren's other acquaintances had survived the red year. Some university professors had been taken east. Most political, economic, and military leaders had been arrested. In Laid's opinion, the loss of moral faith and courage was the worst consequence of the Soviet occupation. However, he thought that Estonian society had not collapsed and there was sufficient basis for recovery. ${ }^{36}$

Harri Moora wrote about a week later. He told that Linnus had last been seen alive in Vyatka on July 9. Moora took a darker view than Laid concerning the consequences of the year of Soviet occupation for Estonians. Although the Estonians had survived physically, the year of untruth and violence had made them spiritually invalids ${ }^{37}$ (further on personal views see Oras, 1948).

Laid wrote more soon after this. Elementary schools were functioning, but it was still unclear whether scientific institutions would start their work. The Germans had plans to establish a German university in Tartu. Laid was optimistic again and wanted to believe that the rights of the Estonians would be restored - undoubtedly referring to a re-establishing of the independent state. ${ }^{38}$ (Zetterberg, 2007, pp. 648-649; Rui, 2006, pp. 321-323) Tallgren passed on the information immediately, at least to Sweden. Already at that point, Sten Karling assumed, on the basis of the German press, that Estonia's independence would not be restored. ${ }^{39}$ Also Laid became more pessimistic, when, for example, no new students were accepted into the university. He thought that help from outside was especially necessary for Estonia now. ${ }^{40}$ All this information undoubtedly served as an impulse for a group of Finnish professors to send a letter to the President of Finland and urge him to investigate what kind of action Finland could take to ensure the existence of the Estonian nation. Predictably, the letter angered the Germans (Salminen, 2008, p. 147; Jokisipilä \& Könönen, 2013, p. 466).

36 Moora's letter to AMT, 31 October 1941 (KK, 1838-1956); AMT's letter to Curman, 11 November 1941 (ATA, 1881-1966).

37 Laid's letter to AMT, 1 November 1941 (KK, 1838-1956).

38 Karling's letter to AMT, 15 November 1941; Curman's letter to AMT, 24 November 1941 (KK, 18381956); AMT's letter to Curman, 11 November 1941 (ATA, 1881-1966).

39 Laid's letter to AMT, 19 November 1941 (KK, 1838-1956).

40 Gustav Suits' letter to AMT, 21 November 1941 (KK, 1838-1956). 
Literature scholar Gustav Suits (1883-1956) hoped that, in case the pessimistic thoughts regarding the improbability of survival of the Estonian national university and culture proved to be true, he could get work in "larger and happier" Finland. By this, he referred to the attempts to annex Eastern Karelia to Finland. ${ }^{41}$

There is a list of destroyed public and private libraries in Estonia among Tallgren's papers, dating most likely from 1941 or 1942 . More than ten collections are listed there, consisting of more than 45,000 books. The aim of the list was most probably to obtain literature from Finland to Estonia. ${ }^{42}$ Finns were still in a difficult situation in their relationship with Estonia: they felt sympathy for Estonians, but Finland could not afford to irritate its ally Germany, which in its turn attempted to prevent Finns and Estonians from personal contacts with each other (Rui, 2006, pp. 325-328).

In December 1941, Tallgren wrote to Curman about his plan to get to Tartu, but admitted that the Germans would hardly allow it, because his attitude towards them was unchanged. Indeed, he did not receive permission to enter. No good news came from Estonia either, as also the university was being Germanised. ${ }^{43}$

After the Swedish legates' visit to Estonia in 1942, Curman had some news to tell, although relatively little, because Moora had written several times to Tallgren during the previous months. ${ }^{44}$

Harri Moora left Tallinn for Tartu in spring 1942 in order to finish some old excavation reports, because "who knows how long we will live, and we will at least leave our work in order after us". ${ }^{45} \mathrm{He}$ ended his letter with the optimistic belief that evil cannot rule forever in the world. Their generation would, though, be punished for its materialism. He supposed that in poverty, people would start building a spiritual world for themselves again and seek help from God. ${ }^{46}$

In late summer 1942, archaeologist and numismatist Jouko Voionmaa (1912-1991) was appointed Finnish liaison officer in the German troops' staff in Estonia. This meant a short revival of archaeological contacts between Finland and Estonia. ${ }^{47}$ Voionmaa did not have permission to take letters to

\footnotetext{
${ }_{41}$ An unidentified sender's [Musikka’s?] letter to AMT, s. d. (KK, 1838-1956). It has been estimated that about $17 \%$ of public library collections in Estonia were destroyed in 1940-1941 (Medijainen, 1991, p. 42).

42 AMT's letter to Curman, 10 December 1941 (ATA, 1881-1966).

43 Curman's letter to AMT, 31 July 1942 (KK, 1838-1956).

44 "kes teab kauaks meie elu on ja siis jäävad vähemalt tööd korraldatult alles."

45 Moora's letter to AMT, 15 June 1942 (KK, 1838-1956).

46 Voionmaa's letter to AMT, 25 August 1942 (KK, 1838-1956).

47 Voionmaa’s letter to AMT, 17 September 1942 (KK, 1838-1956).
} 
Estonia either, but he smuggled them. He was dismissed after just half a year of service, for the Germans accused him of political plotting in Estonia (Voionmaa, 1943).

Via Voionmaa, Tallgren sent his greetings to Estonians, and Voionmaa told Tallgren that he had read extracts of Tallgren's letter, especially to Estonian youth. He had met both Moora and Loorits. He also supposed that there would be work opportunities for a Finnish ethnologist in Estonia and suggested Auvo Hirsjärvi (1909-1998), who was serving the military administration of Eastern Karelia. ${ }^{48}$

Especially Harri Moora was glad about the better possibilities for correspondence. He wrote to Tallgren about his excavations during the summer, but also his concerns about how long falsehood would rule in Estonia and whether they would see its end. He compared the Estonians' attitude to the Finns' faithfulness to their ideas. The same theme had appeared in Moora's letters to Tallgren already in $1940 .{ }^{49}$

Both Tallgren and Moora played a role when a new lecturer of Estonian for the University of Helsinki was sought in 1942. Moora preferred Gustav Suits and, in the second place, Oskar Loorits, who had lost his job in Tartu because of his correspondence with Finns (Rui, 2006, p. 328). In addition to Loorits, Moora mentioned Julius Mägiste (1900-1978), Paul Ariste (1905-1990), and Julius Mark (1890-1959). From Moora's letter we can conclude that Tallgren had thought of Moora as the lecturer, but Moora refused, because he was not competent to teach language and culture. Paul Ariste was elected. ${ }^{50}$

Both Moora's and Laid's letters in late 1942 and in the first days of 1943 give the impression that archaeological life in the Baltics was settling into more or less normal and peaceful veins. In Tartu, Germans had separated the archaeological museum from the university. Carl Engel edited a new archaeological journal in Riga. The printing of Sten Karling's book on Renaissance and Baroque sculpture, which had been interrupted in 1940, was also continued. Everyday work continued once more as usual after a long exceptional period. Scholarly discussions returned to the correspondence little by little, although on a very practical level regarding fieldwork and museums. Moora, Laid, and Indreko were able to carry out some individual excavations in different parts of the country. The

48 Moora’s letter to AMT, 6 September 1942; 11 June 1940 (KK, 1838-1956).

49 Moora's letters to AMT, 20 October 20, 1942; 11 January 1943; Ariste's letters to AMT, 9 November 1942; 19 February 1943 (KK, 1838-1956).

50 Moora's letters to AMT, 21 May 1942, 4 June 1942, 15 June 1942, 16 September 1942; Laid's letter to AMT, 1 January 1943 (KK, 1838-1956). 
letters they wrote to Finland did not, however, contain any detailed information on the finds. ${ }^{51}$ (Johanson et al., 2013, p. 103)

Harri Moora had great doubts regarding whether the Germans would let any Estonian science survive; rather, he suspected they would replace it with a colonial research of stland. $^{52}$ In a critical tone, Moora related that the University of Tartu had been demoted to a mere Hochschule, intended to educate experts in different practical disciplines, instead of functioning as a scientific institution. ${ }^{53}$

Richard Indreko (1900-1961) defended his doctoral thesis on the Mesolithic Stone Age in Estonia in 1941. Tallgren heard about it from Harri Moora and later also Marta Schmiedehelm ${ }^{54}$ (Johanson \& Törv, 2013, p. 47; see also Johanson et al., 2013). Schmiedehelm herself defended her thesis in 1943 (Laul, 2011, p. 229). After the Germans had occupied Ingria, ethnologists Eerik Laid, Gustav Ränk (1902-1998), Paul Ariste, and Ilmar Talve (1919-2007), together with artist Ilmar Linnat (1914-1987), made an expedition to Votians in August and September $1942^{55}$ (Talve, 1990).

When Moora wrote to Tallgren in winter 1943, his letter, the last one he could send to Tallgren, again bore signs of worsening sentiments. The Soviet Union had bombed Tartu and uncertainty prevailed. Signs of German defeat could be seen. Moora mentioned in his letter that Laid was going to send to Tallgren memories of the end of the Bolshevik regime collected from soldiers in Estonia. One copy was kept in the Estonian National Museum, but Laid wanted to get another copy outside Estonia. ${ }^{56}$

In spring 1943, Per Wieselgren asked Tallgren to act as an intermediary in his contacts with people in Estonia whom he had not been able to reach himself, ${ }^{57}$ but Tallgren's connections had actually already broken down at this point.

Along with the approaching German defeat, researchers were also striving to leave Estonia (Rui 2006, pp. 328-330). Ilmar Talve came to Finland in April 1943 in order to join the Finnish army, and continued to Sweden in autumn

\footnotetext{
Moora’s letter to AMT, 19 March 1942 (KK, 1838-1956).

Moora's letter to AMT, 16 December 1942 (KK, 1838-1956).

53 Moora’s letter to AMT, 15 June 1942; Marta Schmiedehelm’s letter to AMT, 7 February 1943 (KK, 18381956).

54 Laid's letter to AMT, 1 January 1943 (KK, 1838-1956).

55 Moora's letter to AMT, 10 February 1943 (KK, 1838-1956).

56 Wieselgren's letter to AMT, 2 April 1943 (KK, 1838-1956).

57 Ilmar Talve's letters to AMT, 7 May 1943; 1 June 1943; 26 June 1943; 3 October 1943 (KK, 1838-1956). The letter that Talve brought from Laid to Tallgren is most probably the one dated to March 17, 1943 (KK, 1838-1956).
} 
1944. He brought letters with him, for example, from Eerik Laid to Tallgren (Talve, 1997b, pp. 279-344, esp. 282-286). ${ }^{58}$

Eerik Laid followed Talve's lead in the summer of 1943 and acted in Helsinki as the director of the Estonian resistance movement office (Rui, 2006, p. 332). In summer 1943, he wrote to Tallgren that he had heard very bad news from Estonia and mentioned rumours that Moora had had to go underground. Thus, rumours began to replace information already a year before the German retreat ${ }^{59}$ (Talve, 1997a, p. 461; Marksoo, 1999, pp. 127-128). Some time later, Richard Indreko followed Laid to Finland. C. A. Nordman wrote to Bengt Thordeman that Germans had done everything they could in order to lose the sympathy they had originally had among the Estonian people and changed their policies too late. ${ }^{60}$ Aarne Äyräpää employed Indreko in winter 1944 to catalogue the Stone Age materials of Äänislinna (Petrozavodsk) Museum in Finnish-occupied Eastern Karelia ${ }^{61}$ (see also Edgren 2013, p. 82).

\section{Ceasefire in Finland and the second Soviet occupation of the Baltic countries}

The landing of the Western allies in France and the advance of the Soviet Union on the eastern front compelled Germany and its allies to retreat in summer 1944. Finland left East Karelia behind and did not stop until the border of 1940. Finland and the Soviet Union signed a ceasefire on 4 September and a truce in Moscow on 19 September.

When Germany retreated from the Baltic countries, the Soviet Union occupied Estonia, Latvia, and Lithuania again during August and September 1944. The city of Tartu suffered major damages when the front once again passed over it. In the last weeks before the Red Army invaded the Baltics, a big wave of refugees migrated West, especially to Sweden (Kumer-Haukanômm, 2006, pp. 1519; Raag, 2006, pp. 71-73; Kangeris, 2006, pp. 46-48). Among them were several archaeologists. Eerik Laid and Richard Indreko continued from Finland to Sweden to avoid being extradited to the Soviet Union. Finnish researchers helped their Estonian refugee colleagues until early autumn 1944, mainly for

Laid's letter to AMT, 24 August 1943 (KK, 1838-1956).

Nordman's letter to Thordeman, 10 November 1943 (ATA, 1915-1976).

60 Richard Indreko's letter to Nordman, 25 January 1944 (SLSA, 1913-1972).

61 Moora's letter to Curman, s. d. 1944 (ATA, 1881-1966). 
humanitarian reasons (Rui, 2006, pp. 334-339). From the personal level, the desire to help also spread to the level of scholarly societies (Salminen, 2008, pp. 170-171).

Valdemārs Ģinters from Latvia made his way to Sweden and Eduards Šturms and Jēkabs Ozols to Germany. Among Estonian refugees were also ethnologists Gustav Ränk and Ilmar Talve, literature scholar Gustav Suits, and linguists Julius Mark, Julius Mägiste, and Ants Oras, all of whom had contacts with Tallgren before the war. Harri Moora, who had belonged to the Estonian resistance committee in 1943-1944, tried to flee to Sweden, but missed the boat, in which he had seats for his family, and had to stay. The last message from Moora to Sigurd Curman in Stockholm arrived by the mediation of an Estonian resistance movement member, economist Hans Ronimois (1912-1984) in 1944² (Marksoo, 1999, pp. 127-129; Salminen, 2012, pp. 104-105).

Eerik Laid could still visit Estonia once from Sweden in September 1944, when the mainland was already completely under the control of the Red Army. He described his feelings to Tallgren:

I could land only briefly on the soil of the home country that had meant so much to me. This loss cuts me even more deeply now. I came back, heavily depressed. [...] I do not feel saved, but a prisoner, and I doubt that I can ever get rid of that feeling. An emigrant's mind is basically strange to me. ${ }^{63}$

In November, he wrote that he had got over the worst of his depression, because everyday life demanded his attention. ${ }^{64}$ Laid soon got a job in his speciality, thanks to his Swedish colleagues with whom he had become acquainted when studying as a grantee in Stockholm in 1934. Especially the director of the Nordic Museum, Sigurd Erixon (1888-1968), and State Antiquarian Sigurd Curman worked for the refugees in Sweden ${ }^{64}$ (Talve, 1998, pp. 77-79, 89-91).

Finns lost contact with the Baltic countries for about ten years in 1944, but their correspondence with Estonian refugees in the West remained lively.

\footnotetext{
62 Eerik Laid's letter to AMT, 7 October 1944 (KK, 1838-1956): "Sain ainult korra maal käia mulle niipalju tähendanud kodumaa pinnal. Seda teravamalt tundub aga nyyd selle kaotus. Tulin tagasi raskelt masendatud meeleolus. [...] Ma ei tunne end pääsnuna vaid vangina ja vaevalt ma sellest tundest kunagi lahti saan. Emigrandi hingeelu on mulle pöhiliselt võöras."

63 Laid's letter to AMT, 24 November 1944 (KK, 1838-1956).

64 Laid's letter to AMT, 30 October 1944 (KK, 1838-1956).
} 
Wartime contacts: the main elements

The next table shows the numbers of letters received by three Finnish archaeologists, A. M. Tallgren, Aarne Äyräpää, and C. A. Nordman, from Estonia and Latvia, as well as refugees or emigrants of these countries in 1939-1944.

\begin{tabular}{|c|c|c|c|c|}
\hline & Estonia & Latvia & Estonian émigrés & Latvian émigrés \\
\hline 1939 & 11 & & & 1 \\
\hline 1940 & 7 & & & 4 \\
\hline 1941 & 6 & & 1 & 2 \\
\hline 1942 & 9 & & & 9 \\
\hline 1943 & 8 & & 5 & 1 \\
\hline 1944 & & & 10 & \\
\hline
\end{tabular}

There were 13 different senders: Francis Balodis, student fraternity Veljesto, Aleksander Hellat, Tommy Hellat, Richard Indreko, Eerik Laid, Harri Moora, Rein Moora, Ants Oras, Mimmi Rütli, Oskar Rütli, Marta Schmiedehelm, and Ilmar Talve. All other letters were addressed to Tallgren, but Harri Moora and Richard Indreko wrote once to both C. A. Nordman ${ }^{65}$ and Aarne Äyräpää, Francis Balodis twice to Äyräpää. ${ }^{66}$ Finnish archaeologists received no letters from Latvia during the war. The only Latvian scholar to write was already living in Stockholm. The amount of letters rose in 1942 almost to the same number as in 1939, which shows how the contacts had improved during the German occupation of Estonia. All letters dated to 1944 were sent by refugees.

For researchers from elsewhere, the Baltic countries belonged to the sphere of interest of Ellis Minns, T. J. Arne, and especially Sigurd Curman. Minns' connection to the Baltic was most probably restricted to his contact with Francis Balodis, but, as stated above, he knew archaeologists from Baltic countries at least by name. Arne also had only brief contacts with colleagues east of the Baltic Sea, and because of his studies in the prehistory of eastern Europe and Russia, this area definitely belonged to the sphere of his scholarly interest. Curman was active in the Swedish organisations established to help Finland and the Baltic countries during the war, and he looked at the situation east of the Baltic Sea also from the point of view of Sweden's own future. Tallgren had a lively correspondence

65 Moora's letter to Nordman, 21 May 1942; Indreko's letter to Nordman, 25 January 1944 (SLSA, 19131972).

66 Indreko's letter to Äyräpää, 10 June 1939; Moora's letter to Äyräpää, 16 June 1939; Balodis' letter to Äyräpää, s. d. 1939, s. d. 1942 (MVA, 1915-1970). 
with Curman especially in 1941 and still to some extent in 1942 (Åman, 2008, pp. 190-198). Curman received letters from two senders, Moora and Balodis. Moora wrote him three times in 1939, once in 1940, and once in 1944. Balodis wrote once in 1940, twice in 1941, twelve times in 1942, seven times in 1943, and nine times in 1944. Among Swedish museum professionals, Curman was the one with the liveliest Baltic contacts, but he could not reach the same scale as especially Tallgren (ATA, 1881-1966, letters from 1939-1944).

What is the overall nature of the correspondence, seen from the point of view of different discussion themes? The situation in the world became a completely dominant theme in the letters between archaeologists in summer 1939. Also, private news was told against that background. Both in Harri Moora's and Ants Oras' letters, scholarly work and the external world appear as polar opposites, but in a different way. For Oras, the world situation was an obstacle to concentrating on his work, whereas for Moora work was a way to escape the strained reality or at least to keep himself together. He did not take up questions of scholarly interpretation, but only referred to practical fieldwork and museum duties. Although Moora emphasised the unnerving situation less than Oras, he was still more fatalistic and presented the idea of the war as a divine punishment for mankind. It is a pity that Oras did not write to Tallgren after 1939, but already at that point, he discussed the future world order and cultural hegemony.

When the broken contacts were restored again in late 1941, Tallgren became active in his attempts to acquire information from the Baltic countries. In some cases, it did not come to him directly, but through refugees, especially Francis Balodis. Despite their low-down mood, Balodis' letters were largely just reports of what he had seen or heard. The same spirit is obvious also in the letters from Harri Moora and Eerik Laid. New aspects appear in the Finnish-Swedish correspondence, especially the discussion on how to help people in Estonia. Social and political issues could not be touched upon (Lang, 2002, pp. 526-527; Marksoo, 1999, pp. 125-128), although most letters did not come by official mail, due to censorship, but via private persons. Archaeological work returned to the discussion in 1942, but there was no scholarly exchange of ideas in the correspondence, as there would have been in peaceful times. Family news formed a secondary line of information. A complete image of life could not be given because of censorship.

As a theme of multilateral international correspondence, the Baltic question was relatively marginal. It did not determine the character of communication within the scholarly community outside the countries immediately involved in the events. 
Contacts from pre-war years enabled the confidential and open-hearted nature of correspondence in exceptional times. What was the overall significance of the contacts to different parties? Did they have a consistent idea of the desired goals? There is no doubt that on the general level, all of them shared the goal of freeing the Baltic countries of external occupiers, but on the practical level, the situation is more complicated. Namely, Estonians and Latvians were not asked, and could not be asked, what kind of measures they would have preferred. Therefore both Tallgren in Finland and Curman in Sweden had to act according to their own ideas of what would be the preferred way. On the personal level, the discussion had notable significance in relieving the tensions experienced personally. It bore a marked imprint of belief in international justice and the restoration of democracy, but often also pessimism that healing the damages caused by the war would be a long process on the general, scholarly, and personal levels.

\section{References}

ATA (1881-1966), Sigurd Curman's collection, Ensk/21, The Antiquarian-Topographical Archive, Swedish National Heritage Board, Stockholm.

(1890-1992), Nils Åberg's collection, Ensk/134, The Antiquarian-Topographical Archive, Swedish National Heritage Board, Stockholm.

(1925-1959), Adolf Schück's collection, Ensk/140, The Antiquarian-Topographical Archive, Swedish National Heritage Board, Stockholm.

- (1915-1976), Bengt Thordeman's collection, Ensk/117, The AntiquarianTopographical Archive, Swedish National Heritage Board, Stockholm.

Åman, A. (2008), Sigurd Curman. Riksantikvarie - Ett porträtt [Sigurd Curman, Antiquarian of State - a portrait], Stockholm: KVHAA, Atlantis.

Balodis, F. (1941), Det äldsta Lettland [The oldest Latvia], Stockholm: P. E. Norstedt \& Söner.

Balodis, F. \& Tentelis, A. (1938), Latviešu vēsture, I sējums [History of Latvia, 1st part], Rīga: Valters un Rapa.

Edgren, T. (2013), Carl Fredrik Meinander, Arkeolog med perspektiv [Carl Fredrik Meinander: an archaeologist with perspective], [Helsingfors]: Museiverkets publikationer 1 .

'Harri Moora 2.III.1900-2.V.1968' (1970), in M. Schmiedehelm, L. Jaanits \& J. Selirand (eds.) Studia archaeologica in memoriam Harri Moora, Tallinn: Valgus, pp. 17-22.

Hietala, M. (2006), 'Tutkijat ja Saksan suunta' [Researchers and the German direction], Historiallinen Arkisto: Tutkijat ja sota, vol. 121, pp. 30-141. 
Johanson, K.; Jonuks, T.; Kriiska, A. \& Tórv, M. (2013), 'From the first people to idols and figurines: Richard Indreko as a scientist,' in K. Johanson \& M. Tórv (eds.) Man, his time, artefacts, and places. Collection of articles dedicated to Richard Indreko, Muinasaja teadus, Tartu: University of Tartu, Institute of History and Archaeology, vol. 19, pp. 95-179.

Johanson, K. \& Tórv, M. (2013), 'The many faces of Richard Indreko,' in K. Johanson \& M. Tôrv (eds.) Man, his time, artefacts, and places. Collection of articles dedicated to Richard Indreko, Muinasaja teadus, Tartu: University of Tartu, Institute of History and Archaeology, vol. 19, pp. 25-92.

Jokisipilä, M. \& Könönen, J. (2013), Kolmannen valtakunnan vieraat. Suomi Hitlerin Saksan vaikutuspiirissä 1933-1944 [The guests of the Third Reich: Finland in the sphere of influence of Hitler's Germany 1933-1944], Helsinki: Otava.

KA (1940), Valtioneuvoston tiedotuselinten arkisto, Muistio koskeva kulttuuripropagandaa ulkomailla Jan. 29, 1940 [The Government Intelligence Organs' archive: Memorandum of cultural propaganda in foreign countries, 29 Jan 1940], Kansallisarkisto, National Archives of Finland, Helsinki.

Kangeris, K. (2006), 'German Plans for Retreat from the Baltics: The Latvian Case,' in K. Kumer-Haukanômm, T. Tosenberg \& T. Tammaru (eds.) Suur pógenemine 1944. Eestlaste lahkumine läände ning selle möjud. Great Exodus in 1944. The flight of Estonians to the West and its influences, Tartu: Tartu Ülikooli Kirjastus, pp. 39-51.

KK (1838-1956), A. M. Tallgren’s correspondence, Coll. 230, Kansalliskirjasto, National Library of Finland, Helsinki.

Kumer-Haukanómm, K. (2006), 'Eestlaste Teisest maailmasôjast tingitud pógenemine läände' [The Estonians' flight to the West in the context of the Second World War], in K. Kumer-Haukanómm, T. Tosenberg \& T. Tammaru (eds.) Suur pógenemine 1944. Eestlaste lahkumine läände ning selle mojud. Great Exodus in 1944. The flight of Estonians to the West and its influences, Tartu: Tartu Ülikooli Kirjastus, pp. 13-38.

Lang, V. (2002), 'Harri Moora teadlase ja ühiskonnategelasena' [Harri Moora as a scholar and a social figure], in H. Runnel \& A. Marksoo (eds.) Moora, H., Meie rahvuskultuuri küsimusi, Tartu: Ilmamaa, pp. 517-533.

(2006), 'The History of Archaeological Research (up to the late 1980s),' in Archaeological Research in Estonia 1865-2005: Estonian Archaeology 1, Tartu University Press, Humaniora: archaeologica, pp. 13-40.

Laul, S. (2011), 'Marta Schmiedehelm - Eine Estin erforscht die altpreussischen [sic] Vorgeschichte,' in M. Schmiedehelm (ed.) Das Gräberfeld am Jaskowska-See in Masuren. Studien zur westmasurischen Kultur der römischen Eisenzeit, Warszawa: Instytut Archeologii Uniwersytetu Warszawskiego, pp. 227-232.

Marksoo, A. (1999), 'Nôukogude luureorganitega seotud ajalugu ja allikakriitika Harri Moora juhtumi näitel' [History of Soviet intelligence organs and source criticism in the Harri Moora case], Ajalooline Ajakiri, no. 3/4, pp. 121-140. 
Medijainen, E. (1991), 'Esimene nôukogude vôimu aasta Eesti raamatukogudes' [The first year of Soviet power in the Estonian libraries], in H. Jürman (ed.) Tsensor Eesti raamatukogudes. Uurimusi Eesti raamatukogunduse ajaloost 3. Eesti Rahvusraamatukogu toimetised/Acta Bibliothecae nationalis Estoniae II, pp. 23-51.

Moora family collection (1927-1968), Personal letter from A. M. Tallgren to H. Moora, s.d. 1940 .

MVA (1828-2015), National Museum of Finland: Diaries 1940-1944, Archives of the National Board of Antiquities, Museoviraston arkisto, Helsinki. Retrieved from http://kulttuuriymparisto.nba.fi/netsovellus/rekisteriportaali/portti/default.aspx [accessed Nov 2015]

— (1915-1970), Aarne Äyräpää’s correspondence, Archives of the National Board of Antiquities, Museoviraston arkisto, Helsinki.

Nordqvist, K. \& Seitsonen, O. (2008), 'Finnish Archaeological Activities in the PresentDay Karelian Republic until 1944,' Fennoscandia archaeologica, vol. XXV, pp. 27-60.

Oras, A. (1948), Baltic Eclipse, London: Victor Gollancz.

Pimiä, T. (2009), Tähtäin idässä. Suomalainen sukukansojen tutkimus toisessa maailmansodassa [Sights on the east, Finnish research of the Finnic peoples in the Second World War], Jyväskylä Studies in Humanities 124, Jyväskylä: Jyväskylän yliopisto. Retrieved from https://jyx.jyu.fi/dspace/bitstream/ handle/123456789/21784/9789513936860.pdf?sequence=1 [accessed Nov 2015]

Rui, T. (2006), 'Tiedemiehet sodan jaloissa. Näkökulmia suomalais-virolaisiin tieteellisiin suhteisiin toisen maailmansodan aikana' [Scientists in times of war: Points of view on Finnish-Estonian scholarly contacts during the Second World War], Historiallinen Arkisto: Tutkijat ja sota, vol. 121, pp. 299-345.

Salminen, T. (2008), Aatteen tiede, Suomalais-Ugrilainen Seura 1883-2008 [Science with Ideology, Finno-Ugrian Society 1883-2008], Suomalaisen Kirjallisuuden Seuran toimituksia 1172, Helsinki: Suomalaisen Kirjallisuuden Seura.

(2012), 'Harri Moora, Ella Kivikoski and Scandinavia,' Fornvännen, no. 2, pp. 96111.

(2014), Kollegat, ystävät ja kiistakumppanit, Suomalaisten arkeologien kansainväliset yhteydet 1870-1950 [Colleagues, Friends and Opponents, The International Contacts of Finnish Archaeologists 1870-1950], Suomen Muinaismuistoyhdistyksen Aikakauskirja, vol. 122, Helsinki: Suomen Muinaismuistoyhdistys.

(2015a), 'C. A. Nordman och hans skandinaviska kontakter'’ Historiska och litteraturhistoriska studier, vol. 90, pp. 171-208.

(2015b), 'Carl Axel Nordmanin ulkomaiset historiallisen ajan tutkijoiden verkostot' [C. A. Nordman's networks of researchers of historical times abroad], SKAS, nos. 3-4, pp. 11-23.

SLSA (1913-1972), Carl Axel Nordmans brevsamling, SLSA 652, Svenska Litteratursällskapet i Finland arkiv, Archives of the Swedish Literature Society in Finland, Helsinki. 
Šnore, E. (1974), 'Arheologiskā pētniecỉba Latvijā’ [Archaeological Research in Latvia], in Latvijas PSR Arheoloğija, Rīga: Zinātne, pp. 10-17.

Talve, I. (1990), 'Matka vatjalaisiin 1942' [A trip to the Votians 1942], Kalevalaseuran vuosikirja vol. 69-70, pp. 46-66.

(1997a), 'Eerik Laid. Äärjooni teaduslikust tegevusest' [Eerik Laid, Contours of scholarly work], in P. Erelt \& H. Runnel (eds.) Laid, E. Paopaigad, Tartu: Ilmamaa, pp. 457-465.

(1997b), Kevad Eestis. Autobiograafia I [Spring in Estonia, Autobiography I], Tartu: Ilmamaa.

(1998), Kutsumatu külaline. Autobiograafia II [An uninvited guest, Autobiography II], Tartu: Ilmamaa.

Voionmaa, J. (1943), Jouko Voionmaa’s letter to Mårten Stenberger, May 12, 1943. Retrieved from http://fornleifur.blog.is/blog/fornleifur/month/2012/12/ [accessed 20 Jun 2013]

Wieselgren, P. (1942), Från hammaren till hakkorset. Estland 1939-1941 [From hammer to swastika, Estonia 1939-1941], Stockholm: Idé och Form.

Zetterberg, S. (2007), Viron historia [History of Estonia], Suomalaisen Kirjallisuuden Seuran toimituksia, vol. 1118, Helsinki: Suomalaisen Kirjallisuuden Seura.

Timo Salminen (b. 1967) is a docent of archaeology at the University of Helsinki. In his work, he has focused on the history of archaeology in Finland and neighbouring countries, with the Finnish archaeologists' expeditions to Russia and Siberia and their international contacts as special research themes. 